Euskal ikerketen aldizkaria | Revue d'études basques |

Revista de estudios vascos | Basque studies review

$5 \mid 2000$

Numéro V

\title{
Compte rendu de Pierre-Alain Greciano, La ville de Mauléon [?] au début du xvi ${ }^{\mathrm{e}}$ siècle
}

\section{Manex Goyhenetche}

\section{OpenEdition}

\section{Journals}

Édition électronique

URL : http://journals.openedition.org/lapurdum/1359

DOI : 10.4000/lapurdum.1359

ISSN : 1965-0655

\section{Éditeur}

IKER

Édition imprimée

Date de publication : 1 octobre 2000

Pagination : 391

ISBN : 2-84127-161-7

ISSN : $1273-3830$

Référence électronique

Manex Goyhenetche, " Compte rendu de Pierre-Alain Greciano, La ville de Mauléon [?] au début du xvi siècle », Lapurdum [En ligne], 5 | 2000, mis en ligne le 01 juin 2009, consulté le 21 septembre 2020. URL : http://journals.openedition.org/lapurdum/1359; DOI : https://doi.org/10.4000/lapurdum.1359 


\section{Compte rendu de Pierre-Alain Greciano, La ville de Mauléon [?] au début du XVI siècle}

Manex Goyhenetche

UMR 5478

C'est avec un vif intérêt que j'avais acquis cet ouvrage l'an dernier, dans une librairie à Bayonne. À vrai dire, il s'agit d'un opuscule de 114 pages dactylographiées édité par une "Association de Recherche Historique » appelée Mémoire de Guyenne. Il est aussi en double exemplaire à la bibliothèque universitaire de la faculté de Bayonne, et, je suppose, dans d'autres bibliothèques.

Lors de l'achat, cet ouvrage m'intéressa beaucoup, car j'y découvris avec surprise, l'existence d'un terrier de 1525, à Mauléon, en « pays de Soule » (p. 2), dont l'existence m'avait complètement échappé. A priori, les sources documentaires et la bibliographie étaient fiables (terrier de 1377, de 1672-1973, ouvrages de Jaurgain, Nussy Saint-Saens, J. M. Régnier).

Néanmoins, quelques détails me laissaient perplexe : sur le plan onomastique, aucun nom basque n'apparaissait, le recensement avait été ordonné par un certain " mossen german de Mauléon, senhor et baron de Mauléon ».

Pour en avoir le cœur net, je résolus, cet été, de consulter directement la source documentaire aux Archives départementales : E 1027. Il n'y a aucune erreur possible, il s'agit du terrier de Mauléon en Barrousse !! Et non en pays de Soule. 